\section{Complete lack of NF-кB activity in IKK1 and IKK2 double-deficient mice: additional defect in neurulation}

\author{
Qiutang Li, ${ }_{1}^{1}$ Gabriela Estepa, ${ }^{1}$ Sylvie Memet, ${ }^{2}$ \\ Alain Israel, ${ }^{2}$ and Inder $M$. Verma ${ }^{1,3}$ \\ ${ }^{1}$ Laboratory of Genetics, The Salk Institute, La Jolla, \\ California 92037 USA; $^{2}$ Institut Pasteur, 715724 Paris, Cedex \\ 15, France
}

NF-кB activity is induced by cytokines, stress, and pathogens. IKK1 and IKK2 are critical IKB kinases in NF- $\mathrm{B}$ activation. In this study mice lacking IKK1 and IKK2 died at E12. Additional defect in neurulation associated with enhanced apoptosis in the neuroepithelium was also observed. MEF cells from IKK1 ${ }^{-/-} / I K K 2^{-/-} \mathrm{em}-$ bryos did not respond to NF- $\mathrm{B}$ inducers. Upon crossing with $\kappa B-l a c Z$ transgenic mice, double-deficient embryos also lost lac $Z$ transgene expression in vascular endothelial cells during development. Our data suggest that IKK1 and IKK2 are essential for NF-кB activation in vivo and have an important role in protecting neurons against excessive apoptosis during development.

Received April 17, 2000; revised version accepted May 26, 2000.

NF- $\mathrm{KB}$ activity is required for the induction of a large number of genes involved in cell growth, differentiation, and development. A wide variety of external stimuli including cytokines, pathogens, stress, and pharmacological agents can lead to the activation of the NF-кB family of transcription factors (Baeuerle and Henkel 1994; Baeuerle and Baichwal 1997). These stimuli induce phosphorylation and subsequent degradation of ІкB inhibitory proteins, thereby releasing NF- $\mathrm{\kappa B}$ proteins for translocation to the nucleus to function as transcription factors (Verma et al. 1995). Phosphorylation of ІкB is mediated by IKK complexes containing two highly homologous ІкB kinases, IKK1 (IKK $\alpha$ ) and IKK2 (IKK $\beta$ ) (DiDonato et al. 1997; Mercurio et al. 1997; Regnier et al. 1997; Woronicz et al. 1997; Zandi et al. 1997; Karin 1999). A scaffolding protein, NEMO (IKK $\gamma$ ), has also been implicated in NF-кB activation (Rothwarf et al. 1998; Yamaoka et al. 1998; Mercurio et al. 1999). IKK1- and IKK2-deficient mice were generated by a gene targeting approach and displayed different spectra of defects (Hu et al. 1999; Li et al. 1999a, b, c; Takeda et al. 1999; Tanaka et al. 1999). IKK2-deficient mice died progressively from E12.5 to E14 because of enhanced apoptosis in liver that could be overcome by mating to TNFR1 $1^{-/}$background (Li et al. 1999b). In contrast, IKK1-deficient mice died at

[Key Words: IKK; NF-кB; knockout; endothelium; apoptosis; NTD] ${ }^{3}$ Corresponding author.

E-MAIL verma@salk.edu; FAX (858) 558-7454. birth with multiple developmental defects in skin, limb, and skeleton (Li et al. 1999a). Because NF-kB activation in mouse embryonic fibroblasts (MEFs) is blocked only partially in the absence of IKK1 or IKK2, it raises the question as to whether genetic redundancy of IKK1 and IKK2 can account for all of the NF-кB activity in mice.

\section{Results and Discussion}

To study the redundant functions of IKK1 and IKK2, we generated compound homozygous mice carrying null alleles of both IKK1 and IKK2 genes. IKK1 $1^{-/-} / I K K 2^{-/-}$ mice were generated from intercrosses of $I K K 1^{+/-}$ $I K K 2^{+/-}$mice. IKK1 $1^{-/-} / I K K 2^{-/-}$embryos were recovered with expected frequency at E11.5, but they died at E12. Nearly $70 \%$ of $I K K 1^{-I-} / I K K 2^{-/-}$embryos revealed a failure of neural tube closure in the hindbrain (Fig. 1) that was not observed in wild-type littermates. The telencephalic vesicle of $I K K 1^{-/-} \mid I K K 2^{-/-}$embryos was smaller than that of wild-type embryos (Fig. 1A). Neural folds at the hindbrain in E9.5 IKK1 $1^{-/-} / \mathrm{IKK} 2^{-/-}$mutants failed to elevate on either side of the midline and did not bend toward each other, whereas the remaining length of the neural tube other than the hindbrain was able to form a tube (Fig. 1B). Hindbrain defects in IKK1 $1^{-/-} / \mathrm{IKK}^{-/-} \mathrm{em}-$ bryos were also revealed by histological examination (Fig. 1C,D). To further define the neural tube defect (NTD) in double mutant embryos, we performed TUNEL assay on the transverse section through the hindbrain of E9.5 embryos. Increased apoptosis was detected in the neuronal epithelium at the hindbrain level (Fig. 1E,F). A massive increase of apoptosis in double mutant liver was detected at around E11.5-E12 (Fig. 1G,H), indicating that

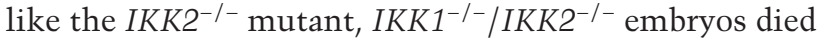
from liver dysfunction. We also observed a twofold increase in apoptosis in the mutant spinal cord and dorsal root ganglia (not shown); however, no defects in neural differentiation were observed (not shown).

Because IKK2 mutant embryos can be rescued from the embryonic lethal to the postnatal stage by inactivation of the TNFR1 gene (Li et al. 1999b), we generated IKK1 $1^{-/-} / \mathrm{IKK} 2^{-/-} / \mathrm{TNFR}^{-/-}$triple mutant mice to assess if $I K K 1^{-I-} / \mathrm{IKK}^{-{ }^{--}}$mice can be rescued by blocking the TNFR1 signal transduction pathway. In TNFR1 $1^{-/}$background, IKK1 $1^{-/-} / \mathrm{IKK} 2^{-/-}$embryos survived to around E16.5 and revealed a morphology similar to $I K K 1^{-/-} \mathrm{em}-$ bryos, such as curled tail and dumpy limb buds (Fig.

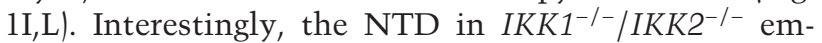
bryos cannot be rescued by loss of the TNFR1 gene. In contrast to $I K K 2^{-/-}$embryos, the phenotypes of $I K K 1^{-/-}$ mutants cannot be rescued either (Fig. 1I-K). Therefore, IKK1 $1^{-/-} / \mathrm{IKK}^{-/-}$mutants revealed combined phenotypes of $I K K 1^{-1-}$ and $I K K 2^{-/-}$mutants, as well as additional defects in neurulation and neuronal survival, suggesting that their functions are distinctive and overlapping during development.

Degradation of $I_{\kappa} B \alpha$ in response to a plethora of external stimulis is preceded by the phosphorylation at Ser-32 

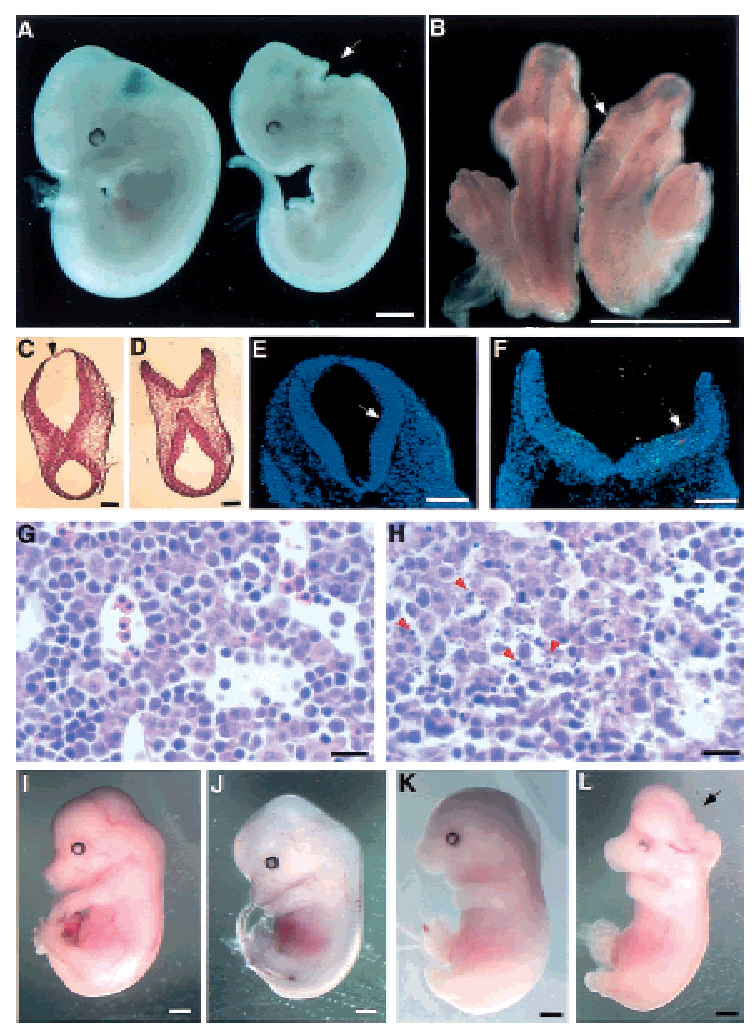

Figure 1. Phenotypes of $I K K 1^{-/-} / I K K 2^{-/-}$embryos. Side $(A)$ and views back $(B)$ of wild type (left) and $I K K 1^{-1-} / I K K 2^{-/-}$(right) embryos at E11.5 $(A)$ and E9.5 $(B)$. The neural tube in the hindbrain region failed to close (arrow). H\&E-stained transverse sections of E9.5 wild type $(C)$ and $I K K 1^{-/-} / I K K 2^{-/-}$mutant $(D)$ at the hindbrain level showing that the roof of the hindbrain (arrow) is present in the wild type but absent in the mutant. TUNEL assay on transverse section of E9.5 wild type $(E)$ and double mutant $(F)$, revealing increased apoptosis (green) in the neuroepithelium of the hindbrain (arrow). Enhanced apoptosis (red arrowhead) was observed in an H\&E-stained liver section from $I K K 1^{-1-} / I K K 2^{-/-}$at E11.5 $(H)$ in comparison with that of a wild type littermate $(G)$. (I-L) Whole-mount pictures of wild-

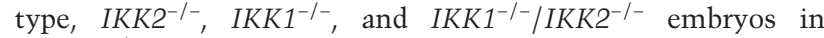
TNFR1 ${ }^{-/}$genetic background at E14.5. No morphologic differences were detected between TNFR1 $1^{-/-}(I)$ and TNFR1 $1^{-/-}$ $I K K 2^{-/-}(J)$ embryos. Phenotypes of dumpy limb buds and curled tail were observed in both TNFR1 $1^{-/-} / \mathrm{IKK}^{-/-}(K)$ and TNFR1 $1^{-/-} /$ $I K K 1^{-/-} / I K K 2^{-/-}(L)$ embryos. In addition, TNFR1 $1^{-/-} / \mathrm{IKK}^{-/-} /$ $I K K 2^{-/-}$embryos also had NTD (arrow in $L$ ). Scale bar, $1 \mathrm{~mm}$ in $A, B$, and $I-L ; 100 \mu \mathrm{m}$ in $C-F$; and $24 \mu \mathrm{m}$ in $G$ and $H$.

and Ser-36 (Verma et al. 1995). To test if loss of IKK1 and IKK2 blocks phosphorylation, degradation of IкB, and subsequent NF- $\mathrm{kB}$ induction, we examined NF- $\mathrm{\kappa B}$ activation in $\mathrm{MEF}$ cells from $I K K 1^{-/-} / \mathrm{IKK}^{-/-}$embryos. First, we examined NF-кB binding activity by gel shift analysis using NF-кB-responsive elements. We failed to detect induced NF- $\kappa$ B binding activity in nuclear extracts from double-deficient MEFs treated with human (h)TNF $\alpha$, IL- $1 \alpha$, and LPS (Fig. 2A). No degradation of

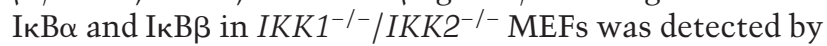
the Western blot analysis, whereas I $\mathrm{I} B \alpha$ and $\mathrm{I} \kappa \mathrm{B} \beta$ were degraded in response to induction in wild-type MEFs
(Fig. 2B). Furthermore, as expected, IкB $\alpha$ was resynthesized rapidly in wild-type MEFs (Fig. 2B). Additionally, IKK complex immunoprecipitated from $I K K 1^{-/-} /$ $I K K 2^{-/-}$MEFs by NEMO (IKK $\gamma$ ) antisera was unable to phosphorylate IкB $\alpha$, IкB $\beta$, and p65 (Fig. 2C). To substantiate our observations further, we performed RNA analysis by Northern blot to examine NF- $\mathrm{B}$ target gene expression upon $\mathrm{TNF} \alpha$ induction. ІкB $\alpha$ expression induced by $\mathrm{TNF} \alpha$ was observed in wild-type MEFs but not in double mutant MEFs (Fig. 2D, E). In contrast, lack of either IKK1 or IKK2 individually resulted in only partial blocking of IкB $\alpha$ induction (Fig. 2D,E). Consistent with the previous observation (Li et al. 1999a, b), NF-кB activation is more attenuated in $I K K 2^{-/-}$than in $I K K 1^{-/-}$ MEFs. We conclude that IKK1 and IKK2 are essential for NF- $\kappa \mathrm{B}$ activation in MEFs by $\mathrm{hTNF} \alpha$, hIL- $1 \alpha$, and LPS.

To further explore the roles of IKK1 and IKK2 in NF- $\kappa \mathrm{B}$ activation in vivo, we introduced a $\kappa B-1 a c Z$ transgene into the double homozygotes as a marker for NF- $\kappa \mathrm{B}$ activity. In mice containing the $\kappa B-l a c Z$ transgene, lacZ expression is driven by $\kappa B$ sites, which mirrors the tran-

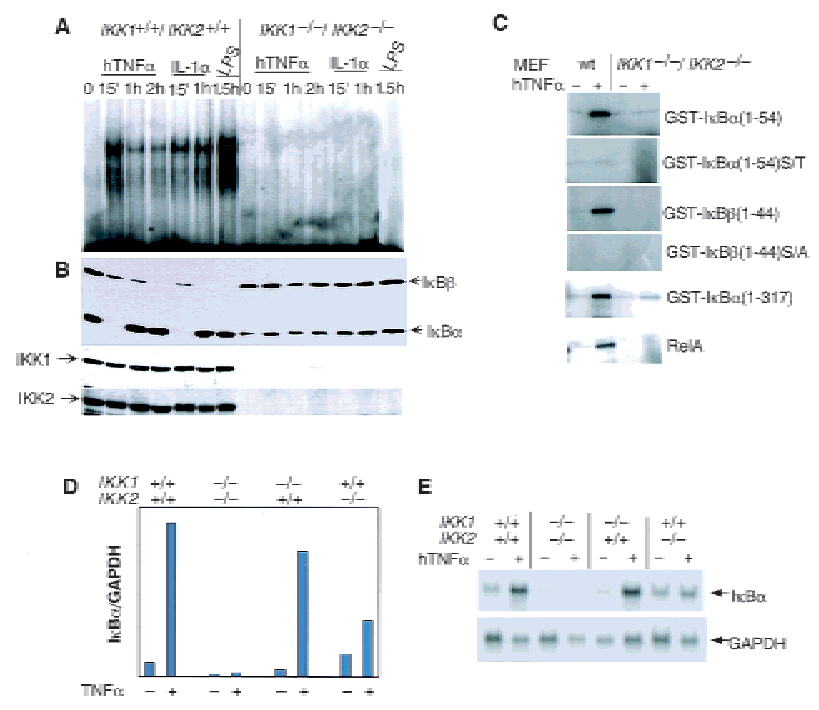

Figure 2. NF- $\mathrm{kB}$ activation is blocked in $I K K 1^{-/-} / I K K 2^{-/-}$ MEFs. (A) No NF- $\kappa B$ DNA binding activity was detectable in IKK1 $1^{-/-} / \mathrm{IKK}^{-/-} \mathrm{MEFs}$ upon induction. Nuclear extracts (5 $\left.\mu \mathrm{g}\right)$ were used for electrophoretic mobility shift analysis with ${ }^{32} \mathrm{P}$ end-labeled HIV-кB oligonucleotide. (B) Induced ІкB degradation was blocked in the absence of IKK1 and IKK2. Cytoplasmic extract $(40 \mu \mathrm{g})$ was used for immunoblotting with ІкB $\alpha$, ІкB $\beta$, IKK1, and IKK2 antisera (Santa Cruz Biotechnology). (C) TNF $\alpha-$ induced kinase activity of the IKK complex for IкB and p 65 was abolished in the absence of IKK1 and IKK2. Cells from three $15-\mathrm{cm}$ plates, untreated or treated with TNF $\alpha$ for $7 \mathrm{~min}$, were lysed and immunoprecipitated with anti-NEMO serum. IP complexes were eluted from the antibody by the synthetic peptide. Equal amounts of eluates were used for kinase assays using the substrate indicated. $(D, E) \mathrm{I} \kappa \mathrm{B} \alpha$ induction by TNF $\alpha$ was abolished in IKK1 and IKK2 deficient MEFs. RNA $(10 \mu \mathrm{g})$ from wild-

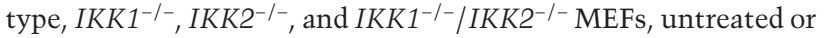
treated with $10 \mathrm{ng} / \mathrm{ml} \mathrm{hTNF} \alpha$ for $1 \mathrm{hr}$ was subjected to Northern blot analysis with probe specific for IкB $\alpha$ and GAPDH. Quantification and original data are shown in $D$ and $E$, respectively. 
scription activity of endogenous NF-кB (Schmidt-Ullrich et al. 1996). To examine NF-кB activity during early mouse development, we first carried out whole-mount $\mathrm{X}$-gal staining on wild-type transgenic embryos. Extensive lacZ expression was observed at E9.5 and E10.5 (Fig. $3 \mathrm{~A}, \mathrm{~B})$ and was detected as early as E8.5 (not shown). Detailed studies on parasagittal sections of whole-mount $\mathrm{X}$-gal-stained embryos revealed that lacZ expression was located at the blood vessel walls, such as intersomitic vasculature (ISV) and dorsal aorta (DA) (Fig. 3C). To further characterize $\beta$-gal-positive cells, we double-labeled the sections immunohistologically using $\beta$-gal antibody and an antibody specific for an endothelial cell marker, PECAM-1. $\beta$-Gal-positive cells in all tissues including neuroepithelium were also PECAM-1 positive, suggesting that they are endothelial cells (Fig. 3D-F). However, not all of the PECAM-1-positive cells, for example, endocardium of heart, express lacZ (Fig. 3G). We conclude that NF- $\mathrm{BB}$ activity is present in vascular endothelial cells during early development.

We examined $\kappa B-1 a c Z$ transgene expression further in

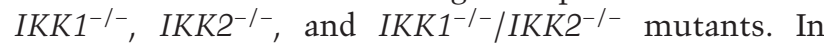
comparison with control embryos, lacZ expression was weaker in $I K K 1^{-/-}$and $I K K 2^{-/-}$mutants and almost un-
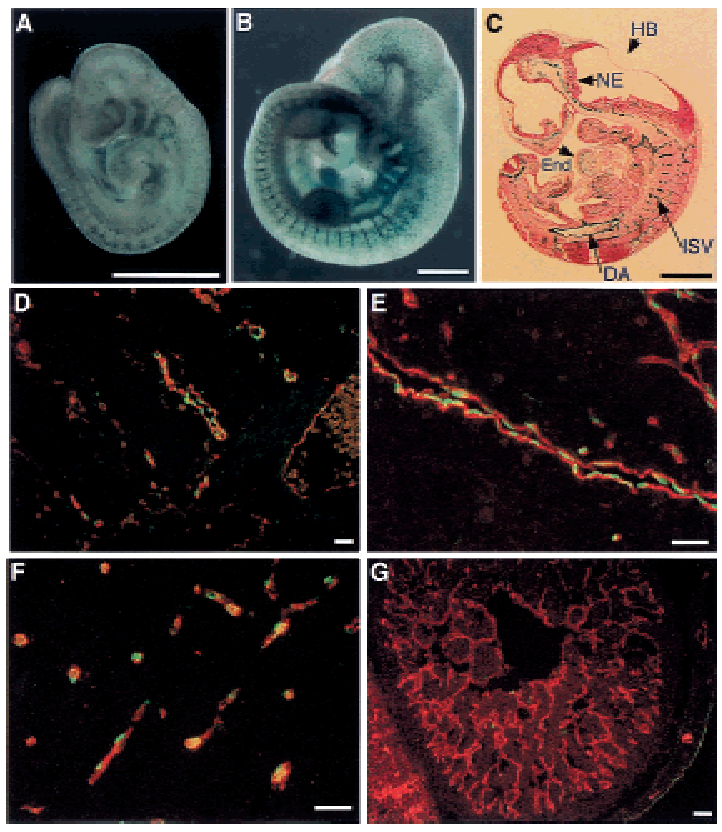

Figure 3. Endothelial cell-specific expression of lacZ in $\kappa B-$ lac $Z$ trangenic mice during early development. Whole-mount $\mathrm{X}$-gal staining of $\kappa B-l a c Z$ transgenic embryos at E9.5 $(A)$ and E10.5 (B). (C) Sagittal sections of an X-gal-stained embryo in $B$ counterstained with nuclear fast red. lacZ expression was readily detected everywhere, especially in vascular vessels such the DA and ISV. (End) Endocardium; (HB) hindbrain; (NE) neuroepithelium. $(D-G) \beta$-Gal (green) and PECAM-1 (red) double staining on the sagittal sections of an E11.5 transgenic embryo. The transgene, NLS-containing $\beta$-gal, is expressed in the nuclei of PECAM-1-positive cells in blood vessels $(D, E)$ and primary capillary plexus at the neuroepithelium $(F)$ but not in PECAM1-positive endocardium $(G)$. Scale bar, $1 \mathrm{~mm}$ in $A-C$ and $24 \mu \mathrm{m}$ in $D-G$.
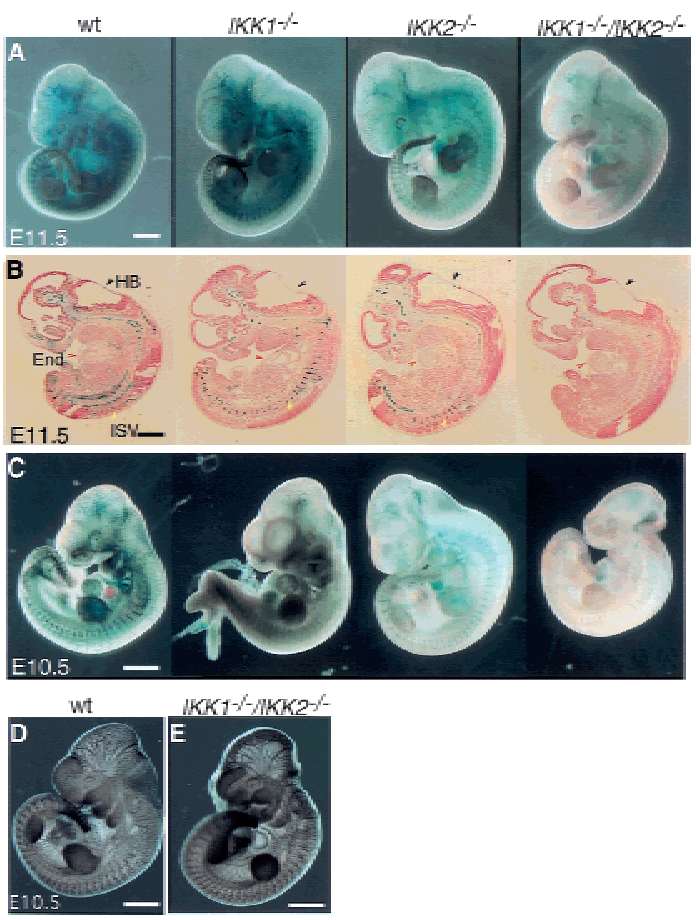

Figure 4. IKK1 and IKK2 are required for NF- $\mathrm{KB}$ activity in vascular endothelial cells. Whole-mount X-gal staining showing different expression levels of transgenes in different IKK mutants at E11.5 $(A)$ and E10.5 $(C)$. (B) Sagittal section of embryos in $A$. X-gal expression in $I K K 1^{-/-} / I K K 2^{-/-}$embryos is lost almost completely; its expression in $I K K 1^{-/-}$and $I K K 2^{-/-}$embryos is also attenuated in comparison with wild-type controls. (See text and legend to Fig. 3 for abbreviations.) Whole-mount PECAM-1 staining of an $I K K 1^{-/-} / I K K 2^{-/-}$mutant $(E)$ and a control littermate $(D)$ at E10.5 revealed normal vasculogenesis in the absence of IKK1 and IKK2 kinases. Scale bar, $1 \mathrm{~mm}$ in $A-E$.

detectable in $I K K 1^{-/-} / I K K 2^{-/-}$embryos (Fig. 4A-C). This result demonstrates that IKK1 and IKK2 are essential for NF-кB activity in vascular endothelial cells during development. We also evaluated vasculogenesis in IKK $1^{-/-} / \mathrm{KK}^{-/-}$embryos by whole-mount PECAM-1 staining. The overall pattern of PECAM-1 staining was similar in both $I K K 1^{-/-} / I K K 2^{-/-}$mutants and in wildtype controls, suggesting normal vasculogenesis in the absence of IKK1 and IKK2 (Fig. 4D,E).

Our results show that IKK1 and IKK2 have a redundant role during neural development, They are integral in preventing excessive apoptosis in liver and neural tissue during development. It is well established that NF-кB activity is required for protecting the liver from TNF $\alpha$ induced apoptosis (Doi et al. 1999; Li et al. 1999b). The involvement of NF-кB in NGF-mediated neuronal survival and in protecting neurons from injury-induced apoptosis has also been suggested recently (Hamanoue et al. 1999; Mattson et al. 2000). Because misregulation of apoptosis has been implicated in NTD (Lill et al. 1997; Yao et al. 1998), it is possible that the NTD in $I K K 1^{-/-}$ $I K K 2^{-/-}$mutants may be a secondary effect of dysregulation of apoptosis. Alternatively, NF- $\mathrm{B}$ may regulate the expression of adhesion molecules important for neu- 
ral tube folding. Increased apoptosis in neural tissue and development of NTD in the absence of NF- $\mathrm{B}$ activity during mouse embryonic development have not be reported to date. Recently NEMO/IKK $\gamma$-deficient mice were generated, which display a phenotype similar to IKK1 and IKK2 double mutants in terms of liver apoptosis and lack of NF- $\kappa$ B activation (Rudolph et al. 2000). However, no NTD or other developmental phenotypes were reported in NEMO-deficient embryos. Thus it would appear that NTD in IKK1 and IKK2 double mutants may be caused at least partly by a NF-кB-independent mechanism. NF-кB-independent functions of IKK1 during development are already hinted at from the genetic analysis of skin phenotype (Li et al. 1999a). Identification of IKK1 downstream targets during development will be required to better understand the cause of the phenotypes. NF- $\mathrm{B}$ activity has been observed previously in blood vessels of adult mice (Schmidt-Ullrich et al. 1996), and it is thought to be important for leukocyte trafficking and regulation of inflammatory responses. Identification of strong constitutive NF- $\mathrm{B}$ activity in endothelial cells during early vasculogenesis is an intriguing observation. It will be of obvious interest to identify NF-кB induced genes involved in endothelial cell development and function. Finally it is important to point out that our data with $\kappa B-1 a c Z$ transgenic mice do not have the sensitivity to exclude other cell types, which may not require IKK1 or IKK2 for NF-кB activation.

\section{Materials and methods}

Generation of $\mathrm{IKK}^{-/-} / \mathrm{IKK} 2^{-/-}$and IKK1 $1^{-/-} / \mathrm{IKK} 2^{-/-}$mice in $\mathrm{TNFR} 1^{-/-}$ background or containing the $\mathrm{\kappa} B-$ lac $Z$ transgene

$I K K 1^{-/-} / I K K 2^{-/-}$mice were generated from intercrosses of $I K K 1^{+/-} /$ $I K \mathrm{~K}^{+/-}$mice. $I K \mathrm{KN}^{+/-} / \mathrm{IKK} 2^{+/-}$mice were generated from the mating of $I K K 1^{+/-}$and $I K K 2^{+/-}$mice (Li et al. $\left.1999 \mathrm{a}, \mathrm{b}\right)$. TNFR $1^{-/-}$mice were obtained from The Jackson Laboratory (Pfeffer et al. 1993). $\kappa B-1 a c Z$ transgenic line 252 was used in this study (Schmidt-Ullrich et al. 1996).

\section{Histology analysis and TUNEL assay}

Embryos were harvested and fixed in $4 \%$ paraformaldehyde (PFA) at $4^{\circ} \mathrm{C}$ overnight. Genotyping was performed on genomic DNAs from yolk sacs. Embryos were grossly examined and photographed after fixation. Fixed embryos were then dehydrated, paraffin embedded, and serially sectioned at $7 \mu \mathrm{m}$. The selected sections were stained with hematoxylin and eosin (H\&E) for routine histologic examination.

TUNEL assay was performed on E9.5 transverse frozen sections using an in situ cell death detection kit (Boehringer Mannheim) and counterstained with DAPI (Vector).

\section{Whole-mount X-gal staining}

Whole-mount X-gal staining was performed as described (Hogan et al. 1994). Embryos were dissected from uteri, and yolk sacs were saved for PCR genotyping. Embryos were fixed in $0.2 \%$ glutaraldehyde solution [0.1 M PBS (pH 7.3), $5 \mathrm{~mm}$ EGTA, $2 \mathrm{~mm} \mathrm{MgCl}_{2}$ ] for $15-30 \mathrm{~min}$. The embryos were washed three times with rinsing buffer $(0.1 \mathrm{M}$ PBS at $\mathrm{pH}$ 7.3, $2 \mathrm{~mm} \mathrm{MgCl}_{2}, 0.01$ sodium deoxycholate, $0.02 \% \mathrm{NP}-40$ ). Embryos were stained with $1 \mathrm{mg} / \mathrm{ml} \mathrm{X-gal} \mathrm{solution}(0.1 \mathrm{~m}$ PBS at $\mathrm{pH} 7.3,2 \mathrm{~mm}$ $\mathrm{MgCl}_{2}, 0.01$ sodium deoxycholate, $0.02 \% \mathrm{NP}-40,5 \mathrm{~mm}$ potassium ferricyanide, $5 \mathrm{~mm}$ potassium ferrocyanide) for $3-6 \mathrm{hr}$ at $37^{\circ} \mathrm{C}$. After staining, the embryos were postfixed with PBS/4\% PFA in PBS for $2 \mathrm{hr}$.

Immunohistochemical staining for $\beta$-gal and PECAM-1

Cryosections from 4\% PFA/PBS-fixed embryos were postfixed in $4 \%$ PFA/PBS for $10 \mathrm{~min}$, washed with PBS, and blocked with PBS-blocking buffer $(0.1 \%$ BSA, $0.2 \%$ powdered skim milk, $0.3 \%$ Triton X-100) for 15 $\mathrm{min}$. The slides were incubated with primary antibodies specific for $\beta$-gal (Promega) and PECMA-1 (PharMingen) for $1 \mathrm{hr}$ at room temperature, washed three times with PBS buffer, and probed with FITC-conjugated donkey anti-mouse (for $\beta$-gal) or Cy3-conjugated donkey anti-rat secondary antibody (for PECAM-1).

Whole-mount PECAM-1 staining

PECAM-1 staining was carried out using anti-mouse PECAM-1 mAb MEC13.3 (PharMingen). Embryos were fixed in $4 \%$ PFA/PBS at $4^{\circ} \mathrm{C}$ for overnight, washed three times with PBS, dehydrated in $\mathrm{MeOH}$, bleached with $5 \% \mathrm{H}_{2} \mathrm{O}_{2}$ in $\mathrm{MeOH}$ for 60 min at room temperature, washed three times with PBST $(0.1 \%$ Tween 20$) / 1 \%$ DMSO, blocked with blocking buffer $(0.1 \%$ BSA, $0.2 \%$ powdered skim milk, $0.3 \%$ Triton X-100) for overnight, and incubated overnight with anti-PECAM-1 antibody (PharMingen, 1:500 dilution in blocking buffer) at room temperature. Following three washes with PBST/1\% DMSO, embryos were incubated with HRP-donkey anti-rat antibody for overnight, and washed with PBST/1\% DMSO and PBST. Color was developed using a DAB kit (Vector Laboratory Inc.).

RNA isolation and Northern blot analysis

Primary MEFs from wild-type, IKK1 $1^{-/-}, I K K 2^{-/-}$, and $I K K 1^{-/-} / I K K 2^{-/-}$ embryos were treated or untreated with $10 \mathrm{ng} / \mathrm{ml} \mathrm{hTNF} \alpha$ for $60 \mathrm{~min}$. Cells were lysed in RNazol B buffer (Tel-Test, Inc.). Total RNA was prepared from MEFs according to the manufacturer's instructions (TelTest, Inc.). Ten micrograms of total RNA was fractionated on formaldehyde agarose gels, blotted onto GeneScreen Plus membrane (Biotechnology Systems), and hybridized with ${ }^{32} \mathrm{P}$-labeled probe from full-length IкB $\alpha$ cDNA. Quick Hyb (Stratagene) was used for Northern analysis. The same membrane was stripped and reprobed with GAPDH as an RNA loading control. The intensities of the hybridization signals were quantitated using a storage phosphorimaging system (Molecular Dynamics).

Western blot analysis and gel shift mobility assays

MEFs with $\sim 90 \%$ confluence on a $10-\mathrm{cm}$ plate were either untreated or treated with $10 \mathrm{ng} / \mathrm{ml}$ hTNF $\alpha$ (Calbiochem), $2 \mathrm{ng} / \mathrm{ml}$ hIL-1 $\alpha$ (Calbiochem), or $10 \mu \mathrm{g} / \mathrm{ml}$ LPS (Sigma) at the indicated times. After treatment, cells were washed with cold PBS, cytoplasmic and nuclear extracts prepared, and Western blot analysis and gel shift binding assays performed as described previously (Miyamoto et al. 1994; Li et al. 1999a).

Immunoprecipitation and kinase assay

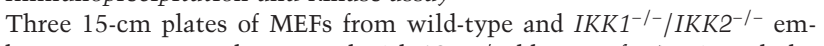
bryos were untreated or treated with $10 \mathrm{ng} / \mathrm{ml} \mathrm{hTNF} \alpha$ for $7 \mathrm{~min}$. Wholecell lysates from each $15-\mathrm{cm}$ plate were prepared and immunoprecipitated with $10 \mu \mathrm{l}$ of anti-NEMO antibody (Mercurio et al. 1999) in $1 \mathrm{ml}$ of immunoprecipitation (IP) buffer (Mercurio et al. 1997). Twenty microliters of protein A was added and samples were rotated for $2 \mathrm{hr}$ at $4^{\circ} \mathrm{C}$. The immunoprecipitates were then washed three times with IP buffer. Samples from all three $15-\mathrm{cm}$ plates were pooled into one tube and washed once with kinase assay (KA) buffer (Mercurio et al. 1997). Sixty micrograms of synthetic peptide in $140 \mu \mathrm{l}$ of KA buffer was added to the protein A beads, and samples were rotated for $6 \mathrm{hr}$ at $4^{\circ} \mathrm{C}$. After a brief spin, the eluates were transferred to new tubes. Twenty microliters of eluates was used for each kinase assay reaction or Western blot analysis.

\section{Acknowledgments}

We thank the following people for their expertise, discussions, and sustained interest in our work: Kuo-Fen Lee, Cornelia Bentley, Samuel L. Pfaff, Kamal Sharma, Qingxian Lu, Frank Mercurio, and members of the Verma laboratroy. Q.L. is supported by a training grant from the NIH. I.M.V. is an American Cancer Society Professor of Molecular Biology and supported by grants from the NIH, the March of Dimes, the Wayne and Gladys Valley Foundation, and the H.N. and Frances C. Berger Foundation.

The publication costs of this article were defrayed in part by payment of page charges. This article must therefore be hereby marked "advertisement" in accordance with 18 USC section 1734 solely to indicate this fact. 


\section{References}

Baeuerle, P.A. and Baichwal, V.R. 1997. NF-kappa B as a frequent target for immunosuppressive and anti-inflammatory molecules. Adv. Im munol. 65: 111-137.

Baeuerle, P.A. and Henkel, T. 1994. Function and activation of NF-kappa $\mathrm{B}$ in the immune system. Annu. Rev. Immunol. 12: 141-179.

DiDonato, J.A., Hayakawa, M., Rothwarf, D.M., Zandi, E., and Karin, M 1997. A cytokine-responsive IkappaB kinase that activates the transcription factor NF-kappaB. Nature 388: 548-554.

Doi, T.S., Marino, M.W., Takahashi, T., Yoshida, T., Sakakura, T., Old L.J., and Obata, Y. 1999. Absence of tumor necrosis factor rescues RelA-deficient mice from embryonic lethality. Proc. Nat1. Acad. Sci. 96: 2994-2999.

Hamanoue, M., Middleton, G., Wyatt, S., Jaffray, E., Hay, R.T., and Davies, A.M. 1999. p75-mediated NF-kappaB activation enhances the survival response of developing sensory neurons to nerve growth factor. Mol. Cell. Neurosci. 14: 28-40.

Hogan, B., beddington, R., Costantini, F., and Lacy, E. 1994. Manipulating the mouse embryo: A laboratory manual, 2nd ed. pp. 373-375. Cold Spring Harbor Laboratory Press, Cold Spring Harbor, NY.

Hu, Y., Baud, V., Delhase, M., Zhang, P., Deerinck, T., Ellisman, M., Johnson, R., and Karin, M. 1999. Abnormal morphogenesis but intact IKK activation in mice lacking the IKKalpha subunit of IkappaB kinase. Science 284: 316-320.

Karin, M. 1999. How NF-kappaB is activated: The role of the IkappaB kinase (IKK) complex. Oncogene 18: 6867-6874.

Li, Q., Lu, Q., Hwang, J.Y., Buscher, D., Lee, K.F., Izpisua-Belmonte, J.C., and Verma, I.M. 1999a. IKK1-deficient mice exhibit abnormal development of skin and skeleton. Genes \& Dev. 13: 13221328

Li, Q., Van Antwerp, D., Mercurio, F., Lee, K.F., and Verma, I.M. 1999b. Severe liver degeneration in mice lacking the IkappaB kinase 2 gene. Science 284: 321-325.

Li, Z.W., Chu, W., Hu, Y., Delhase, M., Deerinck, T., Ellisman, M., Johnson, R., and Karin, M. 1999c. The IKKbeta subunit of IkappaB kinase (IKK) is essential for nuclear factor kappaB activation and prevention of apoptosis. J. Exp. Med. 189: 1839-1845.

Lill, N.L., Grossman, S.R., Ginsberg, D., DeCaprio, J., and Livingston, D.M. 1997. Binding and modulation of p53 by p300/CBP coactivators. Nature 387: 823-827.

Mattson, M.P., Culmsee, C., Yu, Z., and Camandola, S. 2000. Roles of nuclear factor kappaB in neuronal survival and plasticity. J. Neurochem. 74: 443-456.

Mercurio, F., Zhu, H., Murray, B.W., Shevchenko, A., Bennett, B.L., Li, J., Young, D.B., Barbosa, M., Mann, M., Manning, A., and Rao, A. 1997. IKK-1 and IKK-2: Cytokine-activated IkappaB kinases essential for NF- kappaB activation. Science 278: 860-866.

Mercurio, F., Murray, B.W., Shevchenko, A., Bennett, B.L., Young, D.B., Li, J.W., Pascual, G., Motiwala, A., Zhu, H., Mann, M., and Manning, A.M. 1999. IkappaB kinase (IKK)-associated protein 1, a common component of the heterogeneous IKK complex. Mol. Cell. Biol. 19: $1526-1538$

Miyamoto, S., Maki, M., Schmitt, M.J., Hatanaka, M., and Verma, I.M. 1994. Tumor necrosis factor alpha-induced phosphorylation of I kappa B alpha is a signal for its degradation but not dissociation from NF-kappa B. Proc. Natl. Acad. Sci. 91: 12740-12744.

Pfeffer, K., Matsuyama, T., Kundig, T.M., Wakeham, A., Kishihara, K., Shahinian, A., Wiegmann, K., Ohashi, P.S., Kronke, M., and Mak, T.W. 1993. Mice deficient for the $55 \mathrm{kd}$ tumor necrosis factor receptor are resistant to endotoxic shock, yet succumb to L. monocytogenes infection. Cell 73: 457-467.

Regnier, C.H., Song, H.Y., Gao, X., Goeddel, D.V., Cao, Z., and Rothe, M. 1997. Identification and characterization of an IkappaB kinase. Cell 90: $373-383$

Rothwarf, D.M., Zandi, E., Natoli, G., and Karin, M. 1998. IKK-gamma is an essential regulatory subunit of the IkappaB kinase complex. $\mathrm{Na}$ ture 395: 297-300

Rudolph, D., Yeh, W.C., Wakeham, A., Rudolph, B., Nallainathan, D. Potter, J., Elia, A.J., and Mak, T.W. 2000. Severe liver degeneration and lack of NF-кB activation in NEMO/IKK $\gamma$-deficient mice. Genes \& Dev. 14: 854-862.

Schmidt-Ullrich, R., Memet, S., Lilienbaum, A., Feuillard, J., Raphael, M., and Israel, A. 1996. NF-kappaB activity in transgenic mice: De- velopmental regulation and tissue specificity. Development 122: $2117-2128$

Takeda, K., Takeuchi, O., Tsujimura, T., Itami, S., Adachi, O., Kawai, T., Sanjo, H., Yoshikawa, K., Terada, N., and Akira, S. 1999. Limb and skin abnormalities in mice lacking IKKalpha. Science 284: 313-316.

Tanaka, M., Fuentes, M.E., Yamaguchi, K., Durnin, M.H., Dalrymple, S.A., Hardy, K.L., and Goeddel, D.V. 1999. Embryonic lethality, liver degeneration, and impaired NF-kappa B activation in IKK-beta-deficient mice. Immunity 10: 421-429.

Verma, I.M., Stevenson, J.K., Schwarz, E.M., Van Antwerp, D., and Miyamoto, S. 1995. Rel/NF-кB/IкB family: Intimate tales of association and dissociation. Genes \& Dev. 9: 2723-2735.

Woronicz, J.D., Gao, X., Cao, Z., Rothe, M., and Goeddel, D.V. 1997. IkappaB kinase-beta: NF-kappaB activation and complex formation with IkappaB kinase-alpha and NIK. Science 278: 866-869.

Yamaoka, S., Courtois, G., Bessia, C., Whiteside, S.T., Weil, R., Agou, F., Kirk, H.E., Kay, R.J., and Israel, A. 1998. Complementation cloning of NEMO, a component of the IkappaB kinase complex essential for NF-kappaB activation. Cell 93: 1231-1240

Yao, T.P., Oh, S.P., Fuchs, M., Zhou, N.D., Ch'ng, L.E., Newsome, D. Bronson, R.T., Li, E., Livingston, D.M., and Eckner, R. 1998. Gene dosage-dependent embryonic development and proliferation defects in mice lacking the transcriptional integrator p300. Cell 93: 361-372.

Zandi, E., Rothwarf, D.M., Delhase, M., Hayakawa, M. and Karin, M. 1997. The IkappaB kinase complex (IKK) contains two kinase subunits, IKKalpha and IKKbeta, necessary for IkappaB phosphorylation and NF-kappaB activation. Cell 91: 243-252. 


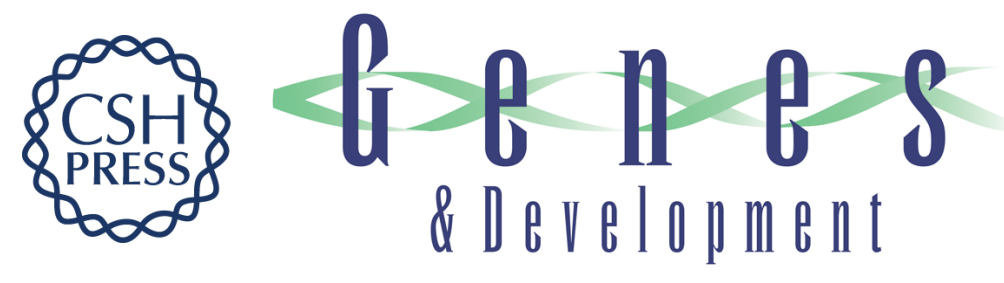

\section{Complete lack of NF- $\kappa B$ activity in IKK1 and IKK2 double-deficient mice: additional defect in neurulation}

Qiutang Li, Gabriela Estepa, Sylvie Memet, et al.

Genes Dev. 2000, 14:

Access the most recent version at doi:10.1101/gad.14.14.1729

References

This article cites 27 articles, 13 of which can be accessed free at: http://genesdev.cshlp.org/content/14/14/1729.full.html\#ref-list-1

License

Email Alerting

Receive free email alerts when new articles cite this article - sign up in the box at the top Service right corner of the article or click here.

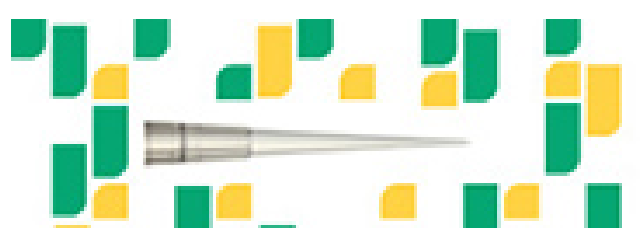

Focused on your science. 